\title{
KESALAHAN SINTAKSIS DALAM PENULISAN TEKS RECOUNT BAHASA INGGRIS
}

\author{
Fadilah Kamal$^{1}$, Zainal Emzir², Aceng Rahmat ${ }^{3}$ \\ Pascasarjana Universitas Negeri Jakarta \\ Ifadilahkamal_pb09s2@mahasiswa.unj.ac.id
}

\begin{abstract}
Abstrak
Penelitian ini dilakukan dengan cara menganalisis teks recount karangan siswa kelas VIII SMP Islamiyah, Depok, sampel diambil 10 karangan teks recount yang ditulis oleh siswa, tahun ajaran 2019/2020. Tujuan dari penelitian ini adalah untuk menemukan jenis kesalahan-kesalahan sintaksis dalam karangan teks recount siswa dan seberapa sering kesalahan itu dibuat. Kesalahankesalahan yang ditemukan diidentifikasi dan diklasifikasikan menggunakan kategori taksonomi linguistik dan siasat permukaan Politzer dan A Ramirez. Hasil yang ditemukan kemudian didefinisikan berdasarkan jenis kesalahan sintaksis. Hasil dari penelitian ini diharapkan dapat membantu mahasiswa dan umum tentang jenis kesalahan yang umum dilakukan siswa dan membantu mereka memutuskan usaha guru untuk menghindari kesalahan tersebut. Dari sepuluh karangan teks recount siswa yang diteliti, ditemukan 141 berdasarkan kategori lingusitik, kesalahan yang paling banyak ditemukan 61 kesalahan penggunaan kata kerja dengan persentase 41\%. Ditemukan 131 kesalahan berdasarkan taksonomi siasat permukaan, kesalahan yang paling banyak ditemukan 58 kesalahan struktur. Bentuk kesalahan yang ditemui merupakan kelalain siswa dalam menggunakan kata kerja yang sesuai dengan struktur yang sesuai dengan kaidah bahasa. Hal tersebut menunjukkan bahwa kesalahan siswa dalam struktur kalimat mengakibatkan kesalahan penggunaan kata kerja yang sesuai.
\end{abstract}

Kata Kunci: Kesalahan Sintaksis, Teks Recount

\begin{abstract}
This research was conducted by analyzing the recount text written by VIII grade students of SMP Islamiyah, Depok, the sample was taken by 10 essays of recount text written by students, school year 2019/2020. The purpose of this study is to find out the types of syntactic errors in Class VIII students' recount text essays and how often they were made. The errors found were identified and classified using the linguistic taxonomic categories and the surface tactics of Politzer and A Ramirez. The results found are then defined based on the type of syntax error. The results of this study are expected to help students and the general public about the types of mistakes students commonly make and help them decide on the teacher's efforts to avoid these mistakes. Of the ten essays of recount texts of students studied, 141 were found based on the linguistic category, with the most errors being found were 61 using verbs with a percentage of $41 \%$. And found 131 errors based on the taxonomy of surface tactics, the most errors found were 58 structural errors. The form of errors encountered is the student's negligence in using verbs in accordance with the structure in accordance with the rules of language. This shows that student errors in sentence structure result in incorrect use of verbs that are appropriate.
\end{abstract}

Keywords: Syntax Error, Text Recount 


\section{PENDAHULUAN}

Pembelajaran bahasa Inggris di SMP (Sekolah Menengah Pertama pada umumnya merupakan pembelajaran bahasa kedua (B2) yang terjadi setelah pemerolehan bahasa ibu (B1) artinya, proses pengguasaan bahasa kedua diperoleh melalui proses pembelajaran bahasa. Dalam proses belajar tersebut memungkinkan terjadinya kesalahan. Kesalahan tersebut diungkapkan oleh Hidayati merupakan kesalahan yang dipandang sebagai hal yang tak terelakan yang dilakukan siswa (Hidayati, 2011:1-2). Terjadinya kesalahan berbahasa tersebut dinyatakan juga oleh Marita dalam penelitiannya bahwa penyimpangan terhadap aturan bahasa yang berlaku dalam penggunaan sebuah bahasa. Kesalahan berbahasa dapat dilakukan oleh siapa saja, baik pembelajar bahasa pertama (B1) atau bahasa kedua (B2). Kesalahan berbahasa dapat terjadi dalam setiap tataran linguistik, artinya dapat dijumpai pada tataran fonologi, morfologi, sintaksis, wacana dan semantik (Marita, 2013: 19).

Kesalahan tersebut dapat terjadi karena adanya perbedaan struktur antara B1 dan B2 dan proses pemelajaran B2 akan cenderung semakin sulit (Tarigan, 2011: 19). Artinya, kesalahan tersebut dapat tejadi pada keterampilan menulis karena dalam proses menulis diperlukan penguasaan kompetensi linguistik seseorang, kemampuan atau pengetahuan seseorang akan aspek-aspek kebahasaan yang antara lain meliputi fonologi, morfologi, sintaksis dan semantik tata bahasa/struktur, kosa kata, tata bunyi, tanda baca, ejaan, sandi tulisan, dan sebagainya. Basserad dan Errad menyatakan bahwa menulis adalah sebuah sistem visual dan bentuk bahasa yang berbeda dengan berbicara yang menggunakan tanda atau grafik tertentu yang menunjukkan unit-unit linguistik (Besserat, 2008: 56).

Pada tingkat literasi awal keterampilan menulis dapat diartikan sebagai kemampuan untuk memvisualisasikan rangkaian alfabet sehingga membentuk sebuah kata yang komprehensif. Namun pada tingkat literasi lanjutan menulis berarti sebuah tindakan kreatif untuk menyampaikan ide, pemikiran, gagasan, perasaan dan pandangan. Menulis adalah proses sosial (Widiyarto, 2017). Hal ini berarti bahwa pesan yang terkandung dalam sebuah tulisan harus terkomunikasikan kepada pihak lain dengan baik agar tidak menimbulkan miskomunikasi. Melalui pembelajaran menulis, siswa diharapkan dapat memiliki kompetensi menulis sehingga dapat menerapkan beberapa aspek kebahasaan sehingga dapat menghasilkan tulisan yang baik dan benar.

Kesulitan penguasaan keterampilan menulis bahasa Inggris dialami oleh siswa kelas VIII SMP Islamiyah Depok. Hal tersebut dibuktikan dengan masih banyak ditemukan kesalahan berbahasa dalam teks recount yang merupakan salah satu produk tulisan siswa. Kesalahan berbahasa yang ditemukan pada teks recount tersebut pada umumnya berkenaan dengan aspek tatabahasa, yaitu aspek sintaksis, seperti tampak pada kalimat siswa berikut ini.

\section{(1) "me and her little brother run and safe".}

Kalimat di atas menunjukkan adanya tiga jenis kesalahan. Yang pertama, siswa menggunakan pronominya kepunyaan sebagai objek me untuk menggantikan subjek I. Dalam bahasa Inggris pronomina akan berubah sesuai dengan perannya dalam kalimat. Jika berkedudukan sebagai sujek, bentuk pronomina yang digunakan adalah I, you, we, they, she, he, it (Azar, 2003:171). Karena subjek dalam kalimat tersebut adalah orang pertama, maka pronomina yang digunakan adalah $I$. Yang kedua, siswa menggunakan bentuk verba kala kini run pada konstruksi yang seharusnya menggunakan sistem kata 
lampau. Yang ketiga, siswa tidak menggunakan to be dalam kalimat betuk lampau. Perbaikan kalimat tersebut adalah "I and her little brother ran and were safe".

Terjadinya kesalahan kesalahan penghilangan atau penambahan unsur-unsur gramatikal seperti di atas, menunjukkan kurangya kompetensi bahasa Inggris siswa yang memungkinkan adanya hambatan dalam pembelajaran yang mencakup aspek sintaksis. Menurut Nelson, dalam pembelajaran bahasa, tata bahasa menempati posisi pusat atau memgang peran penting. Pengetahuan tata bahasa yang baik dapat membantu siswa untuk memahami bagaimana menghasilkan kalimat-kalimat yang jelasm menarik, dan tepat (Greenbaum dan Nelson, 2002: 5). Pedapat tersebut didukung oleh pendapat Bailey yang menyatakan bahwa "accucary is one aspect of the total fabric of good writing". Artinya adalah pembelajaran menulis memerulakan ketepatan atau keakurasian setiap komonen bahasa dan setiap aspek tulisan merupakan aspek yang harus diperhatikan (Bailey, 2006: 119). Dengan kata lain, proses pembelajaran menulis membutuhkan proses pemahaman dan ketelitian dalam berbagai aspek kebahasaan, salah satunya adalah struktur bahasa.

Keterampilan menulis merupakan salah satu kompetensi dasar yang terdapat pada silabus pembelajaran bahasa Inggris SMP. Kompetensi tersebut adalah siswa diharapkan mampu menyusun sebuah teks recount lisan dan tulis sangat pendek dan sederhana terkait dengan pengalaman pribadi di waktu lampau (personal recount), dengan memperhatikan fungsi sosial, struktur teks, dan unsur kebahasaan secara benar dan sesuai konteks. (Kementerian Pendidikan dan Kebudayaan, 2016: 23) Teks Recount merupakan teks yang berisi tentang sebuah pengalaman masa lalu atau kejadian yang sudah terjadi yang diceritakan kembali dalam susunan kronologis yang sistematis. Teks recount terdiri atas tiga macam generic structure yaitu; orientation (pengenalan atau pendahuluan), sequence of events (rangkaian kejadian) dan re-orientation. Teks recount menggunakan fitur-fitur kebahasaan seperti past tense, action verb, adverb of time sequence, personal pronoun, conjunction dan time connectors.

Upaya untuk meningkatkan kemampuan menulis teks recount siswa telah banyak dilakukan. Mulyani mencoba meningkatkan kemampuan siswa dalam menulis teks recount dengan memanfaatkan teknologi yaitu dengan memanfaatkan media online wiki di mana siswa berkesempatan menulis, mengedit dan membublikasikan tulisannya (Mulyani dan Al-Hafizh, 2012: 225-229). Penelitian peningkatan menulis tersebut juga dilakukan oleh Marza dengan memanfaatkan teknologi internet yaitu dengan menginisiasi Facebook peer comment (Marza dan Al-Hafizh, 2013: 683-692).

Terdapat beberapa penelitian mengenai kesalahan pada teks recount, salah satunya penelitian yang dilakukan Arifin menunjukkan bahwa siswa banyak melakukan kesalahan leksikogramatikal pada penulisan teks recount. Kesalahan tertinggi adalah kesalahan dalam penggunaan kata, tense, dan action verb (Arifin, 2017: 144-152). Berbeda dengan Arifin yang menemukan kesalahan leksikogramatikal pada penulisan teks recount, Ramli menunjukkan bahwa kesalahan pada penulisan teks recount juga terjadi dari segi konten teks, penggunaan kosa kata, tata bahasa dan mekanisme penulisan (Ramli dkk., 2013: 68). Penelitian lain terkait penulisan teks recount dilakukan oleh Sari yang menyatakan bahwa siswa mengalami banyak kendala dalam menulis. Kendala atau permasalahan yang dihadapi oleh siswa antara lain adalah dalam menggunakan kapitalisasi, tanda baca, penyusunan teks dan tata bahasa (Sari, 2017: 15-22).

Model analisis kesalahan yang dapat digunakan untuk mengidenifikasi kesalahan berbahasa siswa adalah model analisis kesalahan Dulay (1982: 146). Model tersebut membagi jenis kesalahan bahasa berdasarkan taksonomi, yaitu: taksonomi kategori linguistik, taksonomi siasat permukaan, dan taksonomi fek komunikatif, sedangkan 
model analisis yang digunakan pada penelitian ini mengacu pada Dulay dengan referensi hasil penelitian Politzer dan Ramirez yang mendeskripsikan kesalahan sintaksis berdasarkan kategori linguistik dan siasat permukaan.

Taksonomi kategori linguistik digunakan untuk mengidentifikasi unsur linguistik apa saja yang dipengaruhi kesalahan, meliputi fonologi, sintaksis, morfologi, semantik, leksikal dan wacana. Kesalahan fonologi mencakup ucapan bagi bahasa lisan dan ejaan bagi bahasa tulis. Kesalahan morfologi mencakup struktur kata seperti penggunaan prefiks, infiks, sufiks, konfiks, simulfiks, dan perulangan kata. Kesalahan sintaksis berkaitan dengan struktur kalimat yang antara lain mencakup frasa, klausa dan kalimat. Kesalahan leksikal berkaitan dengan pemilihan dan penggunaan kosakata. Dalam penelitian ini mengidentifikasi kesalahan sintaksis dengan lima kategori bahasa, yaitu: 1) Noun Pharse, terdiri dari: determiners (DET), nominalization (NOM), number (NUM), use of pronouns (PRO), dan use of preposition (PRE); 2) Verb Pharse, terdiri dari: omissiom of verb (OV), use of progressive tense (UPT), dan agreement of subject and verb (SVA); 3) Verb and Verb Construction (VVC); 4) Word Order (WO); 5) Some Transformation, terdiri dari: negative transformation (NT), question transformation (QT), there transformation (There T), dan subordinate clause transformation (SCT).

Taksonomi siasat permukaan (surface strategy taxonomy) berfokus pada kesalahan berbahasa yang terjadi pada struktur permukaan. Menurut Politzer dan Ramirez, kesalahan pada taksonomi ini meliputi kesalahan penghilangan (omission), kesalahan penambahan (addition), kesalahan pembentukan (misformation) dan kesalahan penyusunan (misordering) (Dulay, 1982: 150).

Kesalahan penghilangan (omission) adalah kesalahan yang biasanya ditandai oleh ketidakhadiran suatu komponen atau bagian yang seharusnya ada dalam suatu susunan bahasa. Kesalahan penambahan (addition) adalah kebalikan dari kesalahan penghilangan (omission), yaitu kesalahan yang ditandai oleh munculnya suatu komponen yang seharusnya tidak muncul. Kesalahan pembentukan (misformation) adalah kesalahan yang ditandai oleh pemakaian bentuk morfem atau struktur yang salah. Siswa menghadirkan suatu unsur atau struktur tertentu tetapi dalam bentuk yang tidak tepat. Kesalahan penyusunan (misordering) adalah kesalahan yang terjadi karena adanya suatu morfem atau kelompok morfem dalam penempatan yang tidak benar dalam suatu ucapan atau ujaran.

Dari penjelasan tersebut peneliti tertarik mengkaji kesalahan sintaksis pada teks recount siswa kelas VIII SMP Islamiyah Depok karena belum ada yang meneliti kesalahan sintaksis berdasarkan kaagori linguistik dan siasat permukaan pada teks recount. Upaya identifikasi kesalahan berbahasa siswa melalui aalisis kealahan berbahasa diharapkan dapat meningkatkan kualitas perencanaan dan pelaksanaan pembelajaran. Khususnya, bagi guru dan pengajar bahasa, penelitia ini dapat dimanfaatkan sebagai masukan atau dasar pertimbangan serta dapat memperkaya bukti empiris dalam pengembangan linguistik kontrastif, khususnya analisis kesalahan berbahasa.

\section{METODE PENELITIAN}

Tujuan penelitian ini adalah untuk memperoleh dan mendeskripsikan gejala kesalahan berbahasa dalam tataran sintaksis dalam karangan teks recount pada siswa SMP. Penelitian ini menghasilkan data deskriptif berupa kata-kata tertulis dari sumber data yang dapat diamati (Moleong, 2006: 4). berdasarkan klasifikasi taksonomi kategori linguistik (linguistic category taxonomy) dan klasifikasi taksonomi siasat permukaan (surface structure taxonomy) berdasarkan teori Politzer dan A. Ramirez. Sumber data 
dalam penelitian ini adalah sepuluh teks recount yang telah ditulis oleh siswa kelas VIII SMP Islamiyah Depok. Data sekunder dikutip dari buku, jurnal, dan internet, sebagai dasar teori untuk menganalisis.

Langkah-langkah yang dilakukan untuk menganalisis data dalam penelitian adalah sebagai berikut: 1) Mengumpulkan hasil tulisan teks recount; 2)Membaca hasil tulisan siswa dengan teliti dan mengidentifikasi kesalahan; 3) Mengklasifikasikan kesalahan berdasarkan jenis kesalahan sintaksis yang dikemukakan oleh Politzer dan Ramirez; 4) Mengidentifikasi kesalahan sintaksis ke dalam tabel analisis yang digunakan. 5) Mendeskripsikan kesalahan-kesalahan sintaksis yang ada; 6) Menjelaskan kesalahan sintaksis yang ada; 7) Mengevaluasi kesalahan sintaksis yang ada; 8) Menginterpretasikan kesalahan sintaksis tersebut; 9) Membuat kesimpulan dari temuantemuan yang ada.

\section{HASIL DAN PEMBAHASAN}

Melalui pengumpulan dan analisis data, ditemukan persentase kesalahan sintaksis kategori linguistik dan siasat permukaan pada teks recount siswa sebagai berikut

Tabel 1 Jumlah dan Persentase Kesalahan Sintaksis dalam Klasifikasi Kategori Linguistk

\begin{tabular}{clcc}
\hline No & \multicolumn{1}{c}{ Kategori Bahasa } & Jumlah Kesalahan & Persentase \\
\hline 1 & Determiner & 7 & $5 \%$ \\
2 & Nominalization & 1 & $1 \%$ \\
3 & Number & 3 & $2 \%$ \\
4 & Use of Pronoun & 29 & $21 \%$ \\
5 & Use of Preposition & 12 & $9 \%$ \\
6 & Omission of Verb & 61 & $42 \%$ \\
7 & Addition of Verb & 2 & $2 \%$ \\
9 & Use of Progressive Tense & - & $0 \%$ \\
10 & Subject Verb Agreement & - & $0 \%$ \\
11 & Verb- and- Verb Construction & - & $0 \%$ \\
12 & Word Order & 24 & $17 \%$ \\
13 & Negative Transformation & 3 & $2 \%$ \\
14 & Question Transformation & - & $-\%$ \\
15 & There Transformation & - & $0 \%$ \\
16 & Subordinate Clause & - & $0 \%$ \\
& Transformation & & $100 \%$ \\
& TOTAL & 141 & \\
\hline
\end{tabular}

Tabel 2 Jumlah dan Persentase Kesalahan Sintaksis dalam Klasifikasi Kategori Siasat Permukaan

\begin{tabular}{clcc}
\hline No & \multicolumn{1}{c}{ Kategori Bahasa } & Jumlah Kesalahan & Persentase \\
\hline 1 & Omission & 23 & $18 \%$ \\
2 & Addition & 16 & $12 \%$ \\
3 & Misformation & 58 & $44 \%$ \\
4 & Misordering & 34 & $26 \%$ \\
& TOTAL & 131 & $100 \%$ \\
\hline
\end{tabular}


Berdasarkan taksonomi kategori lingusitik, kesalahan linguistik secara keseluruhan berjumlah 148 dari 119 kalimat yang ada dalam 10 teks recount siswa, meliputi: 61 kesalahan penggunaan kata kerja, 29 kesalahan penggunaan kata ganti, 24 kesalahan susunan kata, 12 lesalahan penggunaan preposisi, 7 kesalahan penggunaan artikel, 3 kesalahan penggunaan nomor dan transformasi negatif, dan 1 kesalahan nominalisasi dan transformasi pertanyaan. Di antara kesalahan sintaksis di atas, yang paling dominan adalah kesalahan yang berkenaan dengan kelalaian penggunaan kata kerja dengan 61 kesalahan.

Kesalahan penggunaan kata kerja dalam analisis karangan siswa terjadi pada kata kerja yang berhubungan dengan struktur tenses yang meliputi kesalahan penghilangan dan penambahan be, verb, agreement, dan kesalahbentukan kata kerja yang digunakan dalam simpel past tense dan past perfect tense. Kesalahan tersebut berkaitan dengan penggunaan sistem kala (misformation of verbs due to tenses) pada konteks yang bersangkutan. Berikut contoh kalimat yang ditemukan dalam kesalahbentukan kata kerja yang digunakan seharusnya past tense.

\section{(2) I finally permission to parents an I got permission from parents.}

Penggunaan verba permission pada kalimat (2) menunjukkan dua hal. Pertama, siswa menggunakan verba bentuk kala kini untuk konteks yang seharusnya menggunakan verba bentuk kala lampau. Kedua, siswa melakukan kesalahan penulisan konjungsi dengan adanya ketidaklengkapan huruf. Kalimat (2) semestinya diubah menjadi I finally permissed to parents and I got permission from parents.

Kesalahan penggunaan bentuk lampau juga banyak terjadi pada sebagian besar karangan siswa. Penggunaan kata kerja pada bentuk masa lampau menggunakan bentuk kata kerja kedua atau penambahan akhiran (-ed).

(3) When I want a get off it my broken and I fell down at a mine, and I cry because if hurt my leg round, and my friends there is to my house you know that I am in,

Pada contoh nomor (3), siswa menggunakan verba kala kini untuk konteks yang seharusnya menggunakan verba bentuk kala lampau. Kata kerja want, cry, dan there pada kalimat tersebut seharusnya ditulis dengan penambahan (-ed). Kalimat (3) semestinya diubah menjadi When I wanted to get off it my broken and I fell down at a mine, and I cried because it, if hurt my leg round, and my friends visited my house to know my conditions,

Dari analisis tersebut menunjukkan bahwa pola-pola kesalahan penggunaan verba yang sering ditemukan dalam tulisan siswa berupa penghilangan dan penambahan be, verb, agreement, dan kesalahbentukan kata kerja yang digunakan dalam simpel past tense dan past perfect tense. Hal tersebut menunjukkan bahwa beberapa siswa masih kurang memahami struktur dan kaidah penggunaan verba pada bentuk kala lampau. Kesalahan m.msiswa menciptakan struktur yang menyimpang oleh karena pengalamannya mengenai struktur terdahulu dalam B2 (Richards, 1974:174). Dengan kata lain, siswa menerapkan pengalamannya mengenai struktur terdahulu pada situasi baru yang tidak sama.

Kesalahan pada frase verbal yang ditemukan pada karangan siswa juga ditemukan dalam beberapa kalimat. Kesalahan ini tidak hanya disebabkan oleh generalisasi namun juga disebabkan oleh perumusan konsep yang keliru, seperti pada kalimat berikut. 


\section{(4) Because had not was there for three years.}

Kesalahan yang terjadi pada kalimat (4) menunjukkan bahwa pemhaman siswa mengenai sistem verba bantu bahasa Inggris masih rendah. Kalimat tersebut menggunakan kala lampau bentuk kata kerja ketiga yang ditandai oleh keterangan waktu for three years. Artinya, kalimat pernyataan tersebut menjelaskan bahwa selama tiga tahun dia tidak berada di sana. Agar menjadi kalimat yang sesuai dengan struktur dan berterima, kalimat tersebut membutuhkan subjek "we" dan frasa verba diganti menjadi haven't been. Dengan demikian kalimat (4) seharusnya dinyatakan seperti berikut ini: Because we haven't been there for three years.

Selanjutnya, kesalahan penggunaan kata ganti (use of pronoun) yang ditemukan terbesar kedua dalam karangan siswa. Terdapat dua kesalahan yang ditemukan pada penelitian ini, kesalahan pensubtitusian pronoun subjek dan kesalahan pensubtitusia pronoun objek. Berikut contoh kesalahan penggunaan pensubtitusian subjek.

\section{(5) Just $05.00 \mathrm{am}$. My family and me take a vacation to beach karangsari.}

Penggunaan pronoun "me" pada kalimat tersebut tidak tepat karena kata ganti me seharusnya digunaan sebagai kata ganti objek pada kalimat. Pronoun "me" dalam kalimat tersebut seharusnya diganti dengan kata ganti orang pertama sebagai subjek yang seharusnya ditulis menjadi $I$. Dengan demikian kalimat tersebut seharusnya ditulis menjadi Just 05.00 am. My family and I take a vacation to beach karangsari.

Berikut kalimat kesalahan pensubttusian objek dalam karangan siswa.

\section{(6) I finished we teacher buy's ticket's.}

Penggunaan pronoun "we" pada kalimat tersebut tidak tepat karena kata ganti we seharusnya digunakan sebagai kata ganti subjek pada kalimat. Pronoun "we" dalam kalimat tersebut seharusnya diganti dengan kata ganti kepunyaan, yang seharusnya ditulis menjadi our. Dengan demikian kalimat tersebut seharusnya ditulis menjadi I finished after our teacher bought tickets

Berikutnya, kesalahan dalam urutan kata (word order). Kesalahan ini ditemukan kesalahan sebanyak 24 data pada urutan head and modifier, contoh pada kalimat berikut. (6) Once everything is ready, we go straight to the beach carita karangsari.

Kesalahan urutan kata pada kalimat tersebut pada kata the beach carita karangsari yang seharusnya pada bentuk kalimat tersebut di awali dengan head terlebih dahulu kemudian modifiernya, semestinya menjadi the carita karangsari beach.

Kesalahan berikutnya adalah penggunaan preposisi. Pada penelitian ini ditemukan pengilangan preposisi dan pensubtitusian preposisi yang tidak tepat dengan preposisi lain. Berikut contoh kalimat yang merupakan kesalahan dalam penghilangan preposisi.

(7) Frist time, night, around 08.00 Pm, I went with mom, and auntie, to pick up my brother in Bogor.

Kalimat (7) menerangkan keadaan waktu pada malam hari ditunjukkan dengan kata "night". Kata yang menunjukkan waktu tersebut seharusnya digunakan preposisi yang spesifik namun kesalahan pada kalimat tersebut tidak menggunakan preposisi "at". 
Semestinya kalimat tersebut ditulis menjadi Frist time, at night, around $08.00 \mathrm{Pm}$, I went with mom, and auntie, to pick up my brother in Bogor.

Selanjutnya, kesalahan penggunaan preposisi yang tidak tepat terdapat pada contoh berikut.

(8) After a holiday in Solo city for 5 days me and family went back te Depok.

Kesalahan pada kalimat (8) tersebut menunjukkan ketidaktepatan preposisi "te" yang termasuk kesalahan dalam pensubtitusian preposisi yang tidak tepat dengan preposisi lain. Semestinya preposisi yang digunakan pada kalimat tersebut adalah "to" dan kalimat yang benar adalah After spending holiday in Solo for 5 days, I_and family went back to Depok.

Berikutya, kesalahan pada penggunaan determiners. Berdasarkan hasil analisis ditemukan sebanyak tujuh data yang salah menggunaan determiners dalam karangan siswa. Kesalahan yang ditemukan berupa pensubtitusian artikel yang tidak tepat dengan artikel yang lain dan penambahan artikel. Berikut contoh kalimat yang merupakan pensubtitusian artikel yang tidak tepat dengan artikel yang lain.

(9) After we arrived at home I to rest this is an arading experiente.

Kalimat tersebut merupakan kesalahan pengilangan artikel "a" sebelum kata rest. Penggunaan artikel "to" pada kalimat tersebut tidak tepat semestinya digunakan "a rest". Jadi, kalimat perbaikan dari kalimat (9) tersebut adalah After we arrived house, I take a rest this is an arading experiente. siswa.

Kemudian, contoh kalimat yang merupakan penambahan artikel dalam karangan

(10) However, I want to show the that I was great.

Penambahan artikel "the" pada kalimat (10) tidak tepat karena artikel "the" digunakan untuk sejumlah kondisi dan situasi tertentu. Misalnya, digunakan dalam menyebutkan sesuatu yang sudah pasti. Dalam kalimat tersebut artikel "the" diikuti dengan kata "that" sehingga peletakan artikel tersebut tidak tepat dan semestinya dihilangkan. However, I want to show that I was great.

Selajutnya, kesalahan penggunaan number, berdasarkan hasil analisis ditemukan kesalahan karena pensubtitusian kata benda jamak oleh kata benda tunggal dan sebaliknya, pensubtitusian kata benda tunggal oleh benda jamak. Akan tetapi, apabila kesalahan pada frasa kata benda tersebut dilihat dari perubahan bentuk permukaan, kesalahan tersebut dapat dikategorikan sebagai penghilangan sufiks (-s/es). Berikut contoh kalimat penambahan sufiks (-s/es).

(11) Finally after hiving same visits, we should go to the hotel to stay and continue our study tour the next day.

Dalam kalimat tersebut seharusnya tanpa menggunakan sufiks (-s) karena tidak menunjukkan bentuk present dan bentuk jamak. Penambahan sufik (-s) tersebut merupakan kesalahan penambahan dalam kategori permukaan. Semsetinya kalimat 
tersebut diubah menjadi, Finally after having some visit, we went to the hotel to stay and continue our study tour the next day.

Selanjutnya, trasformasi negatif merupakan kesalahan perubahan pembentukan struktur kalimat negatif. Berdasarkan analisis data karangan siswa ditemukan penghilangan struktur negatif kata kerja bantu. Berikut contoh kalimat yang ditemukan dalam teks karangan siswa berdasarkan permukaan berupa penghilangan struktur negatif.

(12) ... and cleaning and the body and not forgetting to enjoy the food and drink we had prepare from home,...

Kalimat (12) hanya mengguanakan kata "not" dalam bentuk kalimat negatif. Penggunaan tersebut salah, seharusnya digunakan kata "didn't" karena bentuk kata kerjanya "-ing". Semsetinya kalimat tersebut ditulis, ....... and cleaning and the body and didn't forget to enjoy the food and drink we had prepare from home,......

Selanjutnya, kesalahan nominalisasi atau penggunaan kata benda. Dalam hal ini kesalahan penggunaan kata benda hanya ditemukan satu data. Kesalahan tersebut merupakan ketidaktepatan pemilihan kata benda dalam kalimat. Berikut contoh kalimat yang merupakan kesalahan ketidaktepatan penggunaan kata benda.

(13) we a bicycle just around her the house and the night is dark on of the way do I have to go,....

Kalimat (13) menunjukkan kesalahan penggunaan kata benda bicycle yang seharusnya pada kalimat tersebut membutuhkan kata kerja untuk subjek "we". Kesalahan tersebut menyebabkan kesalahan pembentukan struktur. Berdasarkan kesalahan permukaan, kesalahan tersebut merupakan kategori kesalahan kesalahbentukan. Dalam kalimat tersebut seharusnya digunakan bentuk kata kerja cycling. We went cycling just around her house and the night was dark on the way do I have to go,.....

\section{SIMPULAN}

Dari analisis kesalahan sintaksis pada karangan teks recount siswa kelas VIII SMP Islamiyah, Depok, ada tiga kesimpulan, yaitu (1) Data yang dikumpulkan dan diklasifikasikan berdasarkan kategori linguistik dan strategi permukaan menunjukkan dominasi kesalahan dalam penggunaan kata kerja yng mengakibatkan kesalahan dalam struktur yang digunakan dalam kalimat, (2) Klasifikasi kesalahan Politzer dan Ramirez berdasarka linguistik kategori telah terbukti bermanfaat sebagai pedoman untuk mengungkapkan kesalahan jenis. Namun, beberapa jenis kesalahan yang ditemukan di Politzer dan Ramirez tidak muncul dalam penelitian ini. Misalnya, Use of Progressive Tense, Subject Verb Agreement, Question Transformation, There Transformation, Subordinate Clause Transformation. Di sisi lain beberapa jenis kesalahan yang ditemukan dalam penelitian ini tidak terdaftar dalam klasifikasi pedoman, seperti kesalahan pada penulisan kata yang kurang huruf dan terbalik menggunakan hurufnya, dan (3) Dari penelitian ini, ditemukan bahwa jenis kesalahan yang paling uum ditemukan dalam sepuluh karangan siswa adalah kesalahan struktur (misformation), ditemukan 44 kesalahan dengan persentase $58 \%$.

Hasil penelitian ini dapat digunakan oleh guru sebagai rambu-rambu dalam memprediksi kesulitan belajar dan kesalahan berbahasa yang mungkin dialami sisa dalam pembelajaran bahasa kedua. Misalnya, banyak kesalahan yang terjadi pada aspek 
sintaksis yang merupakan indikator bahwa siswa masih mengalami banyak kesulitan dalam menggunakan bentuk kata kerja. Berdasarkan temuan itu, guru bisa melakukan langkah-langkah diagnostik dan preventif. Secara diagnostik, guru bisa melakukan 'penyembuhan' terhadap berbagai kesulitan yang dihadapi siswa da secara preventif guru bisa merencanakan pembelajaran berikutnya lebih efektif bagi siswa.

Hasil penelitian ini juga dapat digunakan oleh guru sebagai bahan pertimbangan dalam menyusun rencana perbaikan yang tepat berdasarkan tingkat kesalahan yang paling dominan yang dilakukan siswa dengan mempertimbangkan klasifikasi kesalahan berdasarkan taksonomi siasat permukaan.

\section{DAFTAR PUSTAKA}

Arifin, A., \& Rois, S. (2017). Kesalahan leksikogramatikal pada teks recount. Jurnal Kata: Penelitian tentang Ilmu Bahasa dan Sastra, 1 (2), 144-152.

Azar, B. S. (2003). Fundamentals of english grammar (3rd ed.). New York: Longman.

Bailey, S. (2006). Academic writing: A handbook for international students (2nd ed.). New York: Routldege.

Besserat, D. S., \& Errad, M. (2008). Handbook of research on writing. New York: Lawrence Erlbaum Associated.

Dulay, H., Burt, M., \& Krashen, S. (1982). Language two. USA: Oxford University Press.

Greenbaum, S., \& Nelson, G. (2002). An introduction to English grammar. Pearson Education.

Hidayati, S. (2011). Error analysis on a short speech: A case of an esl Indonesian learner. Journal of English Culture, Language, Literature, and Education, 5(1), 11-21.

Kementerian Pendidikan dan Kebudayaan. (2016). Silabus mata pelajaran sekolah menengah pertama/madrasah tsanawiyah mata pelajaran bahasa Inggris. Jakarta: Kementerian Pendidikan dan Kebudayaan.

Marita, Y. (2013). Kesalahan phrasal verb dalam esai berbahasa inggris (Penelitian analisis isi pada mahasiswa Universitas Negeri Jakarta). Jakarta: Universitas Negeri Jakarta.

Marza, L., \& Al-Hafizh, M. (2013). Teaching writing recount text to junior high-school students by using Facebook peer-comment. Journal of English Language Teaching, 1(2), 683-692.

Moleong, L. J. (2006). Metodologi penelitian kualitatif. Bandung: PT Remaja Rosdakarya.

Mulyani, U., \& Al-Hafizh, M. (2012). Teaching junior high school students to write recount text through wikis media. Journal of English Language Teaching, 1(1), 225-229. 
Ramli, D., Suhartono, L., \& Novita, D. (2013). An analysis on the students'error in writing recount text. Jurnal Pendidikan Dan Pembelajaran Khatulistiwa, 2(2).

Richards, J. C. (1974). Error analysis: Perspective on second language acquisition. London: Longman Group Limited.

Sari, M. K. (2017). An analysis of students' problem in writing recount text. Jurnal Educative: Journal of Educational Studies, 2(1), 14-21.

Tarigan, H. G. (2011). Pengajaran analisis kesalahan berbahasa. Bandung: Angkasa.

Widiyarto, S. (2017). Pengaruh minat baca dan penguasaan kosa kata terhadap keterampilan menulis eksposisi. Pesona: Jurnal Kajian Bahasa dan Sastra Indonesia, 3(1), 74-80. 